UDC 535.3

PACS: 42.81.PA

\title{
FIBER-OPTIC SENSOR FOR THE EXPRESS CONTROL OF THE CHEMICAL COMPOSITION
}

\author{
Y. P. Sharkan', N. B. Jytov', I. I. Sakalosh', J. J. Ramsden', M. Y. Sichka', \\ I. I. Popovich ${ }^{1}$, S. O. Korposh ${ }^{1}$ \\ ${ }^{1}$ Institute of Solid-State Physics \& Chemistry, Uzhgorod National University, \\ Voloshina St 54, 88000 Uzhgorod, Ukraine, e-mail: shark@univ.uzhgorod.ua \\ 2"Technomedica", Moscow, Russia \\ ${ }^{3}$ Department of Advanced Materials, Cranfield University, MK 43 0AL, UK
}

\section{FIBER-OPTIC SENSOR FOR THE EXPRESS CONTROL OF THE CHEMICAL COMPOSITION}

\section{Y. P. Sharkan, N. B. Jytov, I. I. Sakalosh, J. J. Ramsden, M. Y. Sichka, I. I. Popovich, S. O. Korposh}

\begin{abstract}
On the example of the aqueous-ethanol solutions we proposed fiber-optic sensor system of the evaluation of the concentration of the liquid solutions with the known qualitative composition. The deposition of the thin film chalcogenide layer with the high refractive index permitted to improve in one order the precision of the refractive index measurements of the aqueous solutions for the quartz Y-shaped splitter. We proposed and tested the method of the definition of the aqueous solutions concentration thanks to the measurement of the time of the total drying of the film of the solution on the fiber end, and thanks to the measurements of the changes of the interference signal which appears on the film in course of the drying process.
\end{abstract}

Keywords: Fiber-optic sensor, Fabry-Perot interferometer, aqueous solutions concentration, the process of drying of the film of the solution

\section{ВОЛОКОННО-ОПТИЧНИЙ СЕНСОР ЕКСПРЕСНОГО КОНТРОЛЮ ХІМІЧНОГО СКЛАДУ ВОДНИХ РОЗЧИНІВ}

\section{Й. П. Шаркань, М. Б. Житов, І. І. Сакалош, Дж. Дж. Рамсден,} М. Ю. Січка, I. I. Попович, С.О. Корпош

Анотація. На прикладі водно-спиртових розчинів запропонована волоконно-оптична сенсорна система оцінки концентрації рідких розчинів з відомим якісним складом. Нанесення тонкоплівкового халькогенідного шару з високим показником заломлення дозволило на порядок підвищити точність вимірювання показника заломлення водних розчинів для Y-подібного кварцового розгалуджувача. Запропоновано та випробувано метод визначення концентрації водних розчинів шляхом визначення повного часу висихання плівки розчину на торці волокна, а також вимірюванням змін інтерференційного сигналу, що виникає на плівці в процесі висихання.

Ключові слова: Волоконно-оптичний датчик, інтерферометр Фабрі-Перо, концентрація водних розчинів, процес висихання плівки розчину 


\title{
ВОЛОКОННО-ОПТИЧЕСКИЙ СЕНСОР ЭКСПРЕССНОГО КОНТРОЛЯ ХИМИЧЕСКОГО СОСТАВА ВОДНЫХ РАСТВОРОВ
}

\author{
И. П. Шаркань, Н. Б. Житов, И. И. Сакалош, Дж. Дж. Рамсден, \\ М. Ю. Сичка, И. И. Попович, С. А. Корпош
}

\begin{abstract}
Аннотация. На примере водно-спиртовых растворов предложена волоконно-оптическая сенсорная система оценки концентрации жидких растворов с известным качественным составом. Нанесение тонкопленочного халькогенидного слоя с высоким показателем преломления позволило на порядок повысить точность измерения показателя преломления водных растворов для Ү-образного кварцевого разветвлителя. Предложено и испытано метод определения концентрации водных растворов путем определения полного времени высыхания пленки раствора на торце волокна, а также измерением изменений интерференционного сигнала, который возникает на пленке в процессе высыхания.
\end{abstract}

Ключевые слова: Волоконно-оптический датчик, интерферометр Фабри-Перо, концентрация водных растворов, процесс высыхания пленки раствора

\section{Introduction}

Determination of the chemical composition of liquid solutions continues to be a task of current importance, covering a very wide spectrum of applications ranging from the control of physicochemical technological processes and ecological monitoring to the analysis of medical and biological processes. The development and creation of sensors for rapid analysis is the especially topical. The sensors should also be cheap, small in size, requiring a small amount of the investigated medium and able to work under the conditions of intensive electromagnetic fields and ionizing radiation.

Fiber-optic sensors meet the demands for precise, rapid and reliable monitoring of media of different kinds [1]. The small size of the mono-fiber permits its use for the analysis of a small amount of the investigated medium. This is especially important for medical purposes. Sensors with sensitive elements on the fiber end are suitable for the determination of chemical compositions [2-5]. The sensitive element can either be the fiber end itself or a film or layer from a material sensitive to the influence of investigated medium [6].

The principle of operation of such sensors can be the amplitude measurement [7-9], in which the change of a signal is due to change of absorption or refractive index of the investigated environment, with which the fiber end contacts. More sensitive are interference fiber-optic sensors, in which the film from the investigated material $[10,11]$ or created at the fiber end beforehand the Fabry-Perot interferometer, the parameters of which vary during the interaction with the investigated medium [3], are used in the role of interferometer[12].
In this work, a fiber-optic sensor for the determination of quantitative changes in chemical composition of solutions is presented. The operating principle of the sensor is a method of determination of the reflection coefficient at the boundary between the fiber end and the investigated medium and the determination of the parameters of the film drying process, which occurs at the fiber end during withdrawal of the fiber from solution.

\section{Direct measurements of the solutions concentration}

The most convenient method for the determination of the refractive index of the solutions is the measurement of the amplitude of the inverse light reflection due to reflection coefficient at the boundary between fiber end and investigated medium. In this case, using the single-mode quartz optic fiber the reflection coefficient is defined as follows:

$$
R=\left(\frac{n_{f}-n_{m}}{n_{f}+n_{m}}\right)^{2},
$$

where $n_{f}$ - the refraction coefficient of quartz core of the single-mode fiber; $n_{m}-$ refraction coefficient of the investigated medium.

The sensor (see, please, Fig.1) contains a Yshaped splitter that divides the power equally between the input and output channels. From the input channel the signal propagates into the common channel, which is placed in contact with the sample. The optical signal is reflected from the fiber-sample interface, returns to the common channel, and then propagates into the output channel. The output sig- 
nal is amplified and sent through an ADC to reach a computer for information processing.

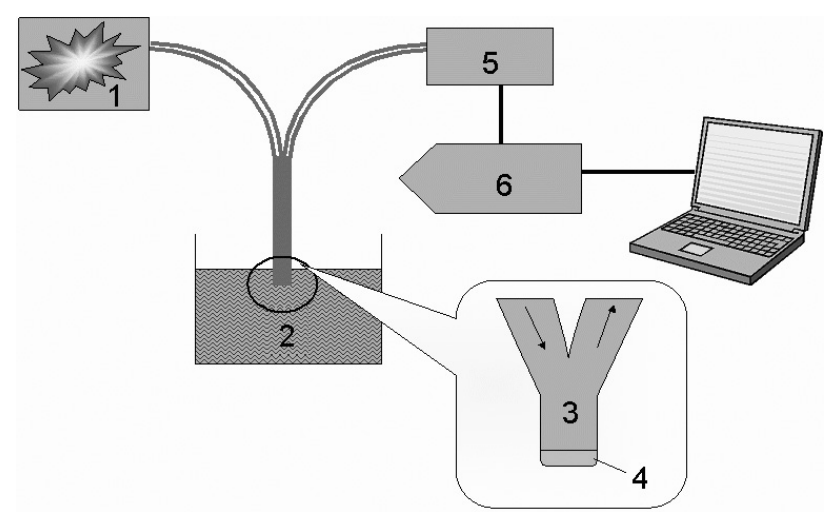

Fig. 1. Scheme of the mono-fiber optical sensor: $1-$ light source $(\lambda=0.95 \mu \mathrm{m}$ in the present work); $2-$ investigated medium (sample); 3 - fiber optic Y-shaped splitter; 4 - liquid film on the fiber end; 5 - photodiode and amplifier; $6-\mathrm{ADC}$.

Fiber-optic Y-shaped splitter contains the quartz fiber with core diameter and covering 8 and $150 \mu \mathrm{m}$, correspondingly, as far as exactly the quartz fibers, comparatively with polymer, due to the chemical stability provide the possibility to investigate the parameters of the physiological liquids in the "in vivo" mode.

The light emitting diode was used as a light source with the illumination wavelength $950 \mathrm{~nm}$ and possesses the width of the emission band at the level of 0.5 of about $30 \mathrm{~nm}$. Unfortunately use of quartz fibers with the core refractive index of 1.45 , leads to a low reflection when measuring the aqueous solutions, in which the refractive index doesn't differ too much from the $n_{f}$ The use of the fibers with the high refractive index, for example chalcogenides, will considerably increase the reflection coefficient at the fiber end-investigated medium interface. Fig. 2 shows the calculated dependences of the fiber end reflection value from the investigated medium for quartz and chalcogenides fibers with a refraction index of 2.05 in the range of refractive indexes inherent to the aqueous solutions. As it is evident from figure, not only reflection value but also the slope considerably increases, and that significantly increases the sensitivity of measurement.

However, the complexity of the creation technology, the Y-shaped splitter on the base of chalcogenide fibers force to search the compromise decision for the given task. In order to increase the sensor sensitivity we used the single-mode quartz Yshaped splitter on the end of the common channel of which was deposited the thin film chalcogenide layer $\mathrm{GeS}_{2}$ with the refractive index 2.05.

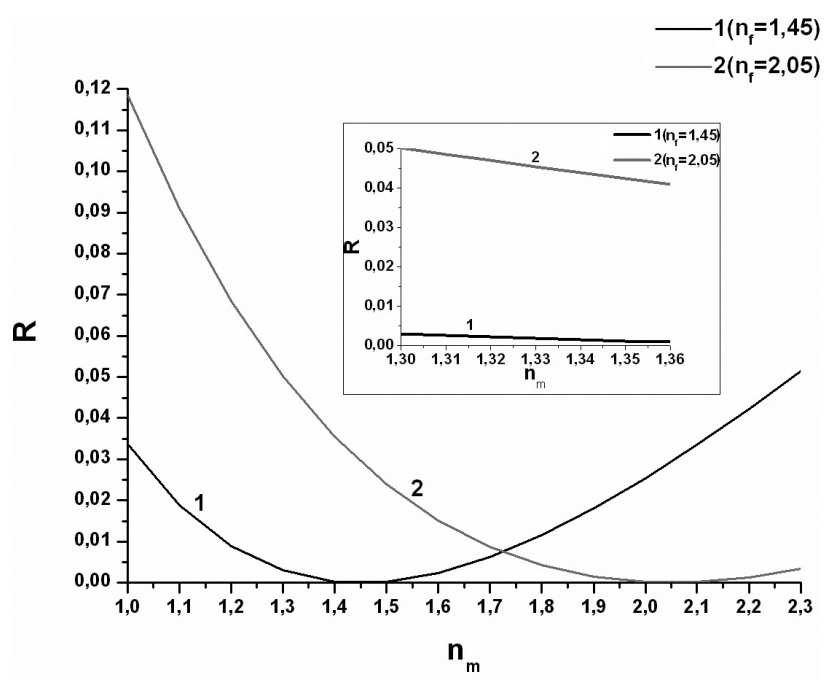

Fig 2. Calculated dependences of fiber end reflection from the investigated medium for a quartz fiber $n_{f}=1.45$ (curve 1), and for a chalcogenide fiber $n_{f}=2.05$ (curve 2); the inset expands the plot for refractive indexes typical for aqueous solutions.

Changing the concentration of the investigated medium, with which the common channel end of the chalcogenide monofiber sensor is in contact, the reflection coe-fficient $\mathrm{R}$ also changes; and change of signal amplitude is recorded:

$$
\begin{aligned}
& U=k R=k \frac{\left(r_{12}+r_{23}\right)^{2}-4 r_{12} r_{23} \sin ^{2}(\delta)}{\left(1+r_{12} r_{23}\right)^{2}-4 r_{12} r_{23} \sin ^{2}(\delta)}, \\
& r_{12}=\frac{n_{f}-n_{l}}{n_{f}+n_{l}}, r_{23}=\frac{n_{l}-n_{m}}{n_{l}+n_{m}}, \delta=\frac{2 \pi n_{l} d}{\lambda},
\end{aligned}
$$

where $\mathrm{k}$ is a proportionality coefficient; $\mathrm{U}-$ the signal amplitude output of the photodiode, $r_{12}$ and $r_{23}$ - reflection coefficients on the boundary quartz single-mode fiber - thin film chalcogenide layer - the investigating medium correspondingly, $\delta-$ phase shift at the light passing at wavelength $\lambda$ through the thin film chalcogenide layer with thickness $d$, $n_{f}-$ the refractive index of the core of the optic single-mode fiber, $n_{l}-$ the refractive index of the thin film chalcogenide layer, $n_{m}-$ the refractive index of the investigated solution. Hence by simply making optical contact of the mono-fiber end of the sensor with the investigated medium it becomes possible to determine the index of refraction of the given medium. Upon a change of the chemical composition of the solution its refractive index varies.

Fig. 3 shows the reflection coefficient of the $f i-$ ber end-air interface and how the reflection coef- 
ficient changes during immersion of the fiber end into solutions containing different concentrations of ethanol.

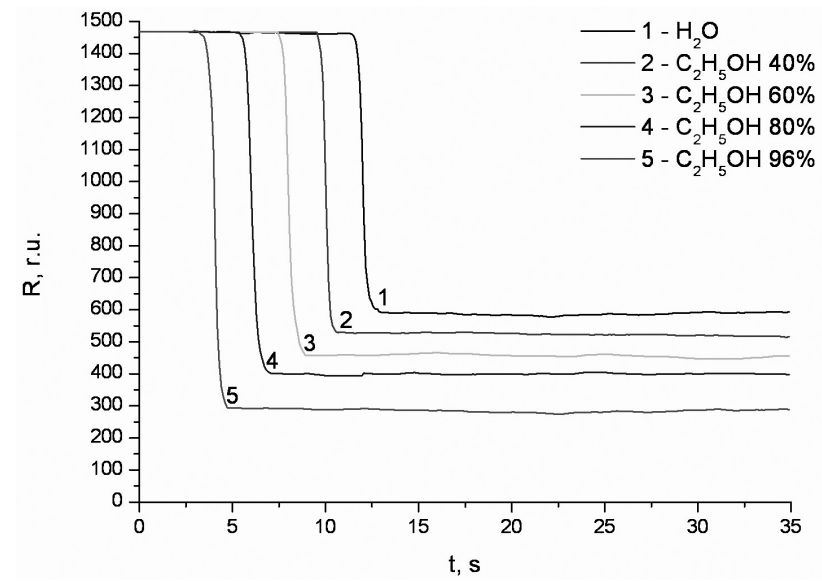

Fig. 3. Experimental determination of the reflectivities of aqueous ethanol solutions and pure water.

From these data the calibration curve of the dependence of the optical signal on the ethanol concentration was plotted (Fig. 4).

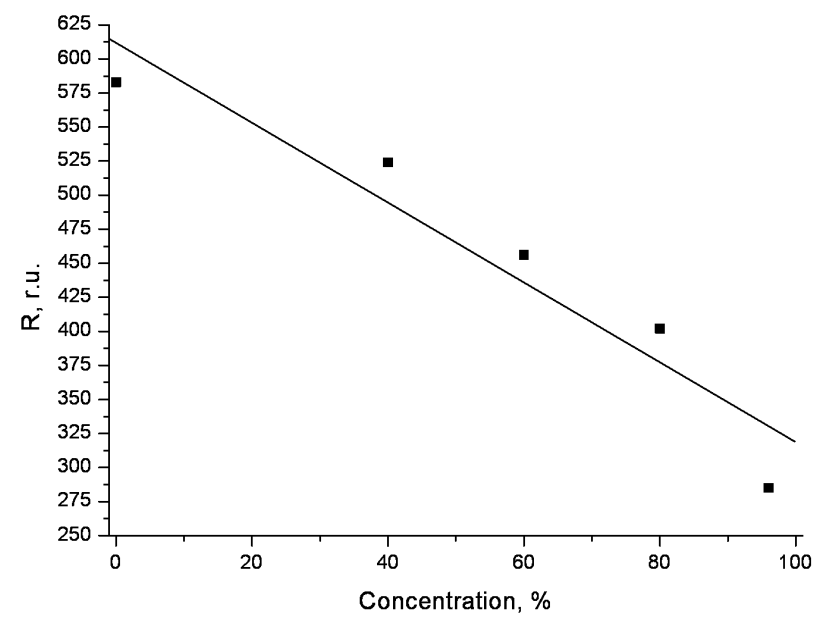

Fig. 4. Calibration curve, linking the optical output signal with ethanol concentration.

The measured value of the refractive indexes of the ethanol solutions are in a good agreement with tabular data [13] within an accuracy $10^{-3}$. It is worth noting that the repeatability of these results was very good. Thus the suggested fiber-optic sensor (Fig. 1) of the amplitude type with single-mode quartz Yshaped splitter permits directly to measure the refractive index of the investigated solution and due to the change of the refractive index to determine the concentration change.

Also, monitoring of the solutions concentration of the known chemical composition may be carried out using the sensor calibration on the standard samples, in this case there is no necessity to measure directly the refractive index of the investigated solution, that permits to use the multi-mode optic fiber and by this to decrease the loses of the optic signal on the optic connections and to increase the reliability of the sensor as a whole.

\section{The process of solution drying on the fiber end}

The second procedure reported here is the study of the dynamics of optical signal changes during the withdrawal of the fiber end from solution and during the drying processes of the film which is formed on the fiber end: during withdrawal of the fiber from a wetting solution, a drop forms on the fiber end, which then remains due to surface tension; its size depends on the composition of the solution from which it is formed (we neglect here any possible changes of the drop composition compared with the bulk composition due to the proximity of the air water interface in the drop).

The drying process was studied with the help of the sensor depicted on figure 1 . It was held at the same conditions of $25{ }^{\circ} \mathrm{C}$ and $55 \%$ relative humidity. Aqueous ethanol solutions were chosen for the experiment.

In order to explain the processes which occur on the fiber end of the sensor after breaking optical contact of the fiber with the investigated medium, a CCD camera was used.

Dependence of the change of the signal value in the process of measurement is shown at Fig.5.

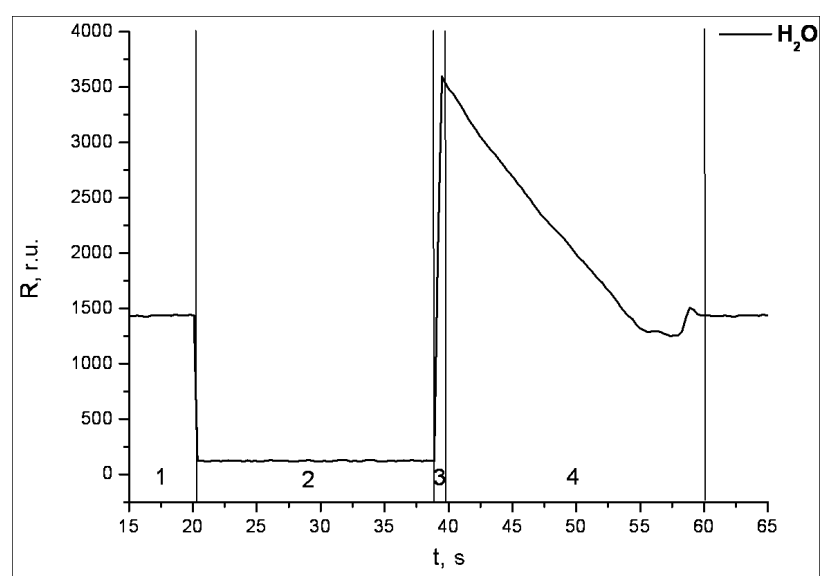

Fig. 5. The change of the signal value in the process of measurement: 1 - the monofiber end-air interface; 2 fiber end-investigated medium interface; 3 - withdrawal of the fiber end from solution and formation of a dropshaped film on the monofiber end; 4 - reduction of film thickness as a result of drying. 
The $1^{\text {st }}$ region corresponds to the fiber end-air interface; the $2^{\text {nd }}$ region to the fiber end-investigated medium interface; the $3^{\text {rd }}$ region to the formation of the drop-shaped film on the fiber end.

The sharp increase of the signal amplitude initially observed is due to the drop-shaped form of the film; all the light is reflected into the monofiber; the subsequent decrease of the signal is due to a change of the drop geometry, and correspondingly the radius of curvature of the spherical mirror, which exists at the investigated medium-air interface is continually changing. Further drying leads to an increase of the radius of curvature, and eventually the solution film on the fiber end becomes plane-parallel and light interference arises, due to the formation of a Fabry-Perot interferometer on the fiber end.

The $4^{\text {th }}$ region shows a changing in the reflected signal as the film thickness on the fiber end decreases due to evaporation of the plane-parallel solution film; when the film thickness reaches the coherence length for the sensor, the interference occurs.

Additional confirmation of such division of the dependence of the amplitude on the film form was received in the course of the investigation of evaporation with the help of the video recording of the process on the CCD camera. On the end of the mono-fiber the drop of the investigated solution is formed. In time the evaporation of the liquid from the end of the mono-fiber occur, the volume decreases and the radius of the drop curvature increases, as a result on the end of the mono-fiber the plane parallel film is formed in which the multiplebeam interference is taking place.

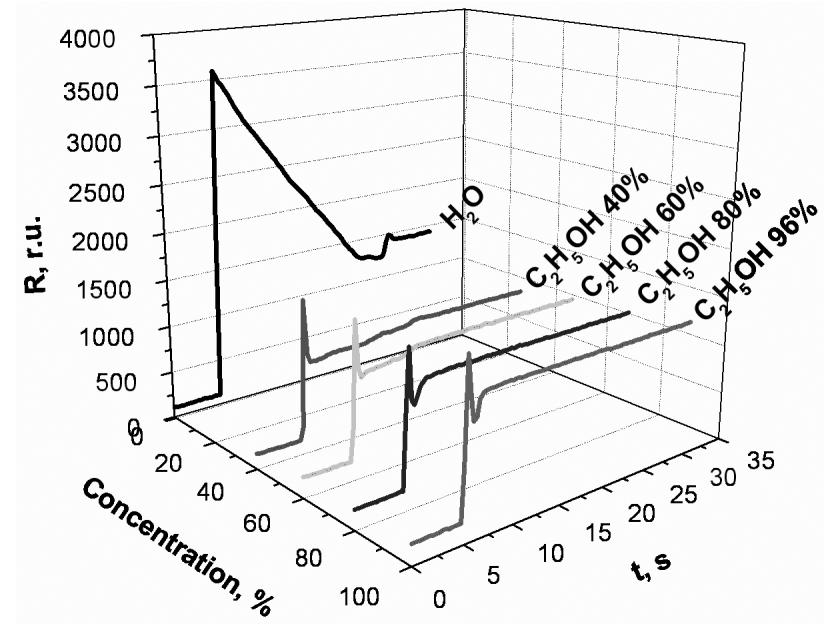

Fig. 6. Drying dynamics for aqueous ethanol solutions of different concentrations.
Fig. 6 shows the optical signal of the drying dynamics for aqueous ethanol solutions of different concentrations. The correlation between the drying time and the solution concentration is evident, i.e. with increasing ethanol concentration film drying is faster. The calibration graph of the drying time dependence on ethanol concentration $\mathrm{C}=\mathrm{C}(\mathrm{t})$ is plotted at Fig. 7.

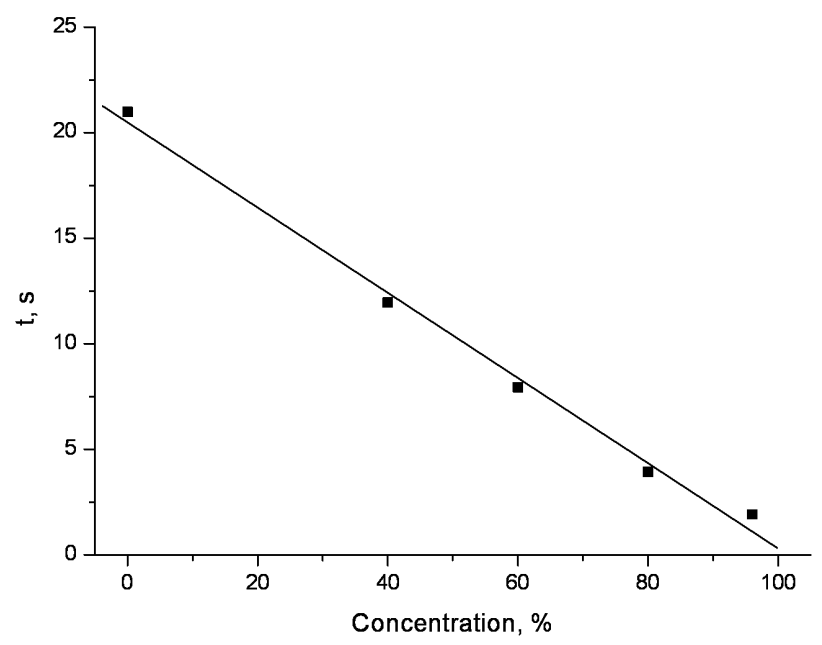

Fig. 7. Dependence of the drying time of the film on the concentration of the aqueous solution of the ethanol.

In such way by the measurement of the time of the process of the total drying of the aqueous solution on the end of the fiber it is possible to determine its concentration.

\section{Interference in the drying solution film}

The interference that appears in the drying film on the fiber end enables the development of interference fiber optic sensors for the determination of solution concentrations, which are more sensitive in comparison with amplitude sensors.

For studying the interference of the solution drying on the fiber end a fiber-optic spectrophotometer (Ocean Optics HR2000) and a white light source (Ocean Optics HL-2000 tungsten halogen lamp) were used. Measurements of the reflection spectrum from the end of the fiber-optic Y-shaped splitter with a diameter of $400 \mu \mathrm{m}$ was carried out; the diameter of the connector of the common channel, which was immersed into the investigated medium, was $3 \mathrm{~mm}$. Aqueous ethanol solutions were also chosen for this experiment.

At Fig. 8, the reflection spectra of the drop formed on the end of the optical connector for different drying time of $50 \%$ aqueous ethanol solution are shown. 
Curve 1 corresponds to the reflection spectrum from the investigated solution when the fiber end is in solution, curve 2 to the spectrum of a solution drop formed on the fiber end after withdrawing it from the investigated liquid. During the drying process a change of reflection occurs due to change of the drop form (curve 3 ). Gradually the radius of curvature of the drop is so increased, that interference in the solution film appear (curve 4), characteristic for a thin-film Fabry-Perot interferometer.

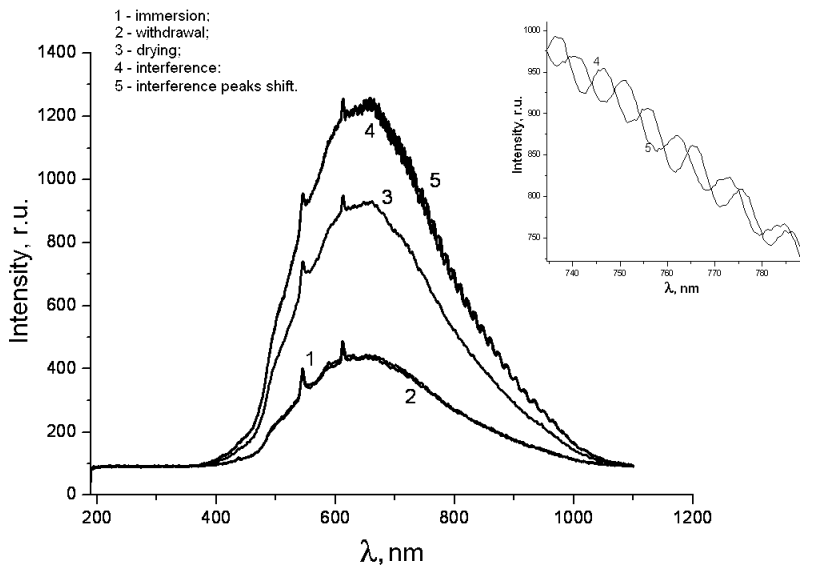

Fig. 8. Reflection spectra of the drop formed on the end of the optical connector for different drying times of a $50 \%$ aqueous ethanol solution. The inset shows an enlargement of part of the curves 4 and 5 .

Further decreasing of the solution film thickness due to drying leads to a shift of the interference maxima in the reflection spectrum (curve 5).

Using the well-known equation for interference, it is possible to assess only the optical thickness $n_{m} d$, but it is impossible to define the absolute value of the refractive index and thickness, because both values vary simultaneously in time for the solutions:

$$
\frac{\lambda_{2}-\lambda_{1}}{\lambda_{2} \lambda_{1}}=2 n_{m} d
$$

where $\lambda_{1}$ and $\lambda_{2}$ are the wavelengths corresponding to the positions of two neighbor interference peaks; $n_{m}$ is refractive index of the solution film at the time of measurement; and $d$ is the geometric film thickness at the time of measurement.

The decrease of the geometrical film thickness takes place due to evaporation; and the change of the index of refraction takes place due to the change of the film chemical composition during the drying, which occurs because of the differential rate of evaporation of the various solution components.

The index of refraction will be constant in time only for pure liquids. Thus, measuring the reflection spectrum, in other words the change of the interference peak positions in time, and calibrating the signals for given solution compositions, application of the given technique for the quantitative determination of solution compositions whose composition is qualitatively known is possible.

However, the processing of the spectral interference curves requires powerful software, because of the presence of large data arrays, and needs also quite expensive and complex hardware, which considerably complicates the application of this method.

Therefore, a system of monitoring the interference in the drying liquid film without spectral determination is offered. For this purpose the scheme depicted in figure 1 was used, single mode quartz fiber was used as the fiber-optic Y-shaped splitter, and a semiconductor laser diode with an illumination wavelength of $1320 \mathrm{~nm}$ and width of emission band at the level of 0.5 of about $5 \mathrm{~nm}$, mean emitted power of $1 \mathrm{~mW}$ and frequency of direct modulation $10 \mathrm{kHz}$, was used as the emitter. The connector of a single mode optical fiber with a diameter of 2.5 $\mathrm{mm}$ was used as a fiber end of the common channel, which was immersed into the investigated solution and on which the drying drop was formed.

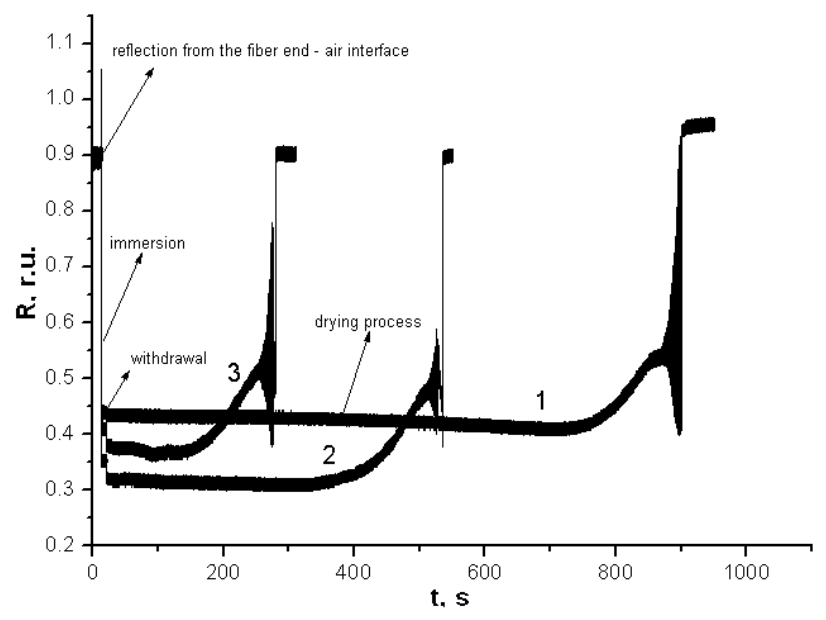

Fig. 9. Reflection changes for the complete process comprising immersion into solution, withdrawal from solution and drying. $1-$ pure water; $2-50 \%$ ethanol solution; $3-80 \%$ ethanol solution.

The drying of aqueous ethanol solution drops of various concentrations formed on the end of the single mode optical fiber was investigated.

Fig. 9 shows the graph of the reflection change for the complete process including immersion into the solution, withdrawal from the solution and drying. Since the diameter of the optical fiber connector end is much bigger than for the technique 
described in the first part of this paper, the times of drying are also much bigger.

The course of the complete drying process, as shown in figure 9, correlates with the data presented in the first part of this work, i.e. with increasing ethanol concentration the time for complete drying is decreased.

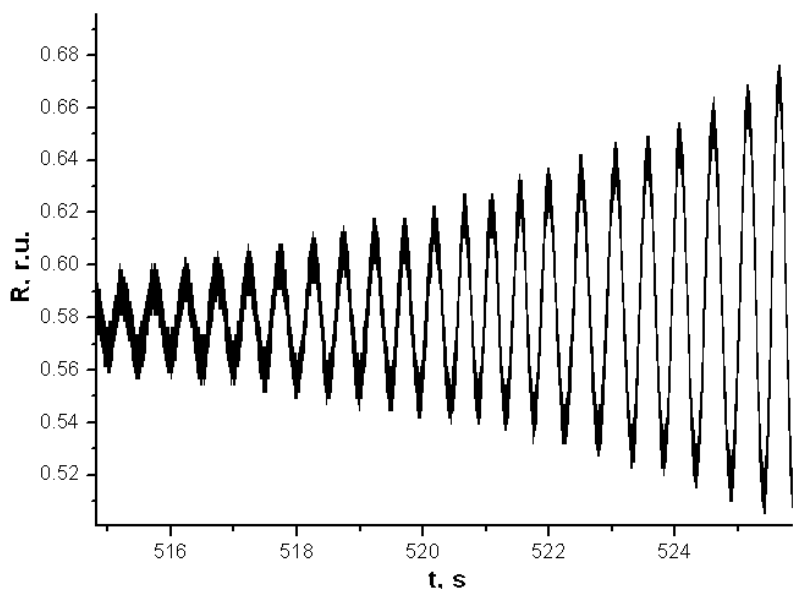

Fig. 10. The interference picture for a $50 \%$ aqueous ethanol solution.

At the same time, for the given measurement system, the region of evaporation of the formed planar film appears more clearly. The reason is connected with the different film geometry at the fiber end (the bigger dimensions in comparison with the first part of this work) and coherence length of the emitter.

The study of the interference picture for the investigated solutions has shown that as well as the spectral changes of reflection during film drying, the rate of the change of the film optical thickness $\left(n_{m} d\right)$ varies in time for solutions. This is evident from the change of period of the interference maxima (Fig. 10 and Table 1). During the film drying of their pure components individually (ethanol or water), the period remains at a constant value.

Thus, by measuring the speed of the period change of the interference maxima the determination of the concentration of the drying liquid is possible. In other words, it is necessary to solve the task of measurement of the distance between the peaks on the interference picture. One possible hardware implementation of a solution to this task is introduction of a differential chain after the signal amplifier (Fig. 11, a), which will allow the creation of impulse fronts from the incoming signal (Fig. 11, b) with a much higher amplitude than the oscillations of the average signal level (Fig. 11, c). After the differential chain, a comparator (threshold device) is placed, which will evaluate the moments of intersection of the impulse with the value of the threshold level (Fig. 11, d).

a

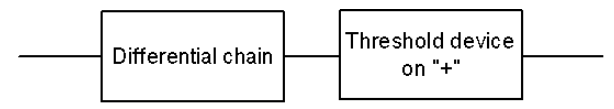

b

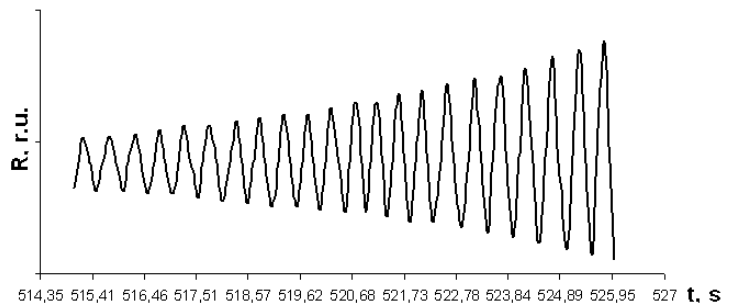

$c$

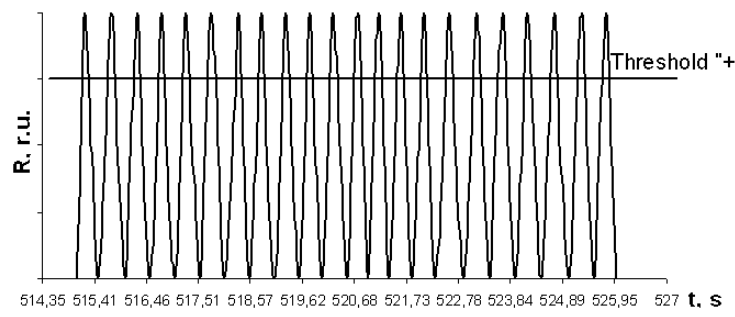

d

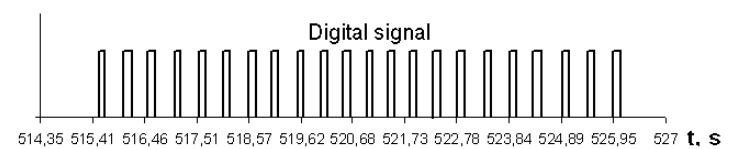

Fig. 11. Schematic illustration of the determination method of the distance between the peaks on the diagram of the interference pattern.

Table 1

Values of the period of the interference maxima for aqueous solutions of ethanol of definite concentrations.

\begin{tabular}{|c|c|c|c|c|}
\hline & \multicolumn{4}{|c|}{$T, \mathbf{s}$} \\
\hline $\begin{array}{c}\text { Number } \\
\text { of period }\end{array}$ & $\mathbf{H}_{\mathbf{2}} \mathbf{O}$ & $\begin{array}{c}\mathbf{C}_{\mathbf{2}} \mathbf{H}_{\mathbf{5}} \mathbf{O H} \\
\mathbf{- 5 0} \mathbf{\%}\end{array}$ & $\begin{array}{c}\mathbf{C}_{\mathbf{2}} \mathbf{H}_{\mathbf{5}} \mathbf{O H} \\
\mathbf{- 8 0}\end{array}$ & $\begin{array}{c}\mathbf{C}_{\mathbf{2}} \mathbf{H}_{\mathbf{5}} \mathbf{O H} \\
\mathbf{- 9 6} \mathbf{\%}\end{array}$ \\
\hline 1 & 1.6809 & 1.0588 & 0.6856 & 0.4874 \\
\hline 2 & 1.6816 & 1.0630 & 0.6901 & 0.4867 \\
\hline 3 & 1.6808 & 1.0658 & 0.6930 & 0.4853 \\
\hline 4 & 1.6813 & 1.0697 & 0.6975 & 0.4873 \\
\hline 5 & 1.6803 & 1.0731 & 0.7012 & 0.4863 \\
\hline 6 & 1.6812 & 1.0776 & 0.7035 & 0.4867 \\
\hline 7 & 1.6813 & 1.0816 & 0.7078 & 0.4853 \\
\hline 8 & 1.6805 & 1.0847 & 0.7109 & 0.4873 \\
\hline 9 & 1.6812 & 1.0877 & 0.7157 & 0.4874 \\
\hline 10 & 1.6808 & 1.0921 & 0.7189 & 0.4863 \\
\hline 11 & 1.6816 & 1.0961 & 0.7222 & 0.4853 \\
\hline
\end{tabular}

Hence, the periods of the interference maxima will be estimated. Further measurement of the temporal distance between impulses can be accomplished by filling the measured interval by time impulses and counting them, which can be easily carried out with the help of a personal computer.

On the base of the received results the plot of the dependence of the middle value of the period of the 
interference maxima on the concentration of the aqueous ethanol solution was constructed (Fig. 12), which permits to measure the ethanol concentration in aqueous solutions.

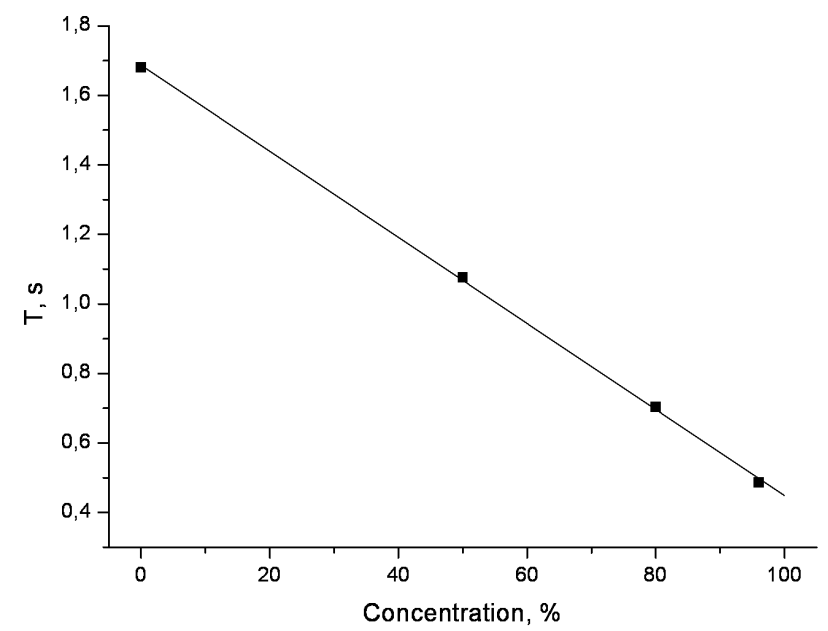

Fig. 12. Dependence of the middle value of the period of the interference maxima on the concentration of the aqueous ethanol solution.

The method of determination of the components concentration for the qualitatively known solution composition was developed that permits to observe the quantitative changes in the composition of the film of the investigated solution and also according to the value of the change of the period of the interference maxima in the process of the measurement, to determine whether the investigated solution is ideal or not ideal [14].

\section{Conclusions}

The work carried out and discussion have shown that:

1. By attaching a chalcogenide glass fiber with a high refractive index to the common channel of a fiber-optic Y-shaped splitter, the sensitivity of the refractometer is increased by almost one order of magnitude compared with conventional silica glass fibers.

2. The measurement of the changes in the reflection coefficient during drying of a solution film on the end of the optical fiber allows the sensitive determination of the concentration of aqueous solutions whose composition is known qualitatively.

\section{References}

1. E. Udd "Fiber Optic Sensors: An Introduction for Engineers and Scientists" // Wiley-Interscience, 1st edn., 1991.
2. A. Cusano, A. Cutolo, Michele Giordano, and Luigi Nicolais "Optoelectronic Refractive Index Measurements: Application to Smart Processing" // IEEE Sens. J. 3 (6), 781-787, 2003.

3. M. Giordano, M. Russo, A. Cusano, and G. Mensitieri "An high sensitivity optical sensor for chloroform vapours detection based on nanometric film of $\Delta$-form syndiotactic polystyrene" // Sens. Actuators B, 2004.

4. A. Cusano, G. V. Persiano, M. Russo, and M. Giordano "Novel optoelectronic sensing system for thin polymer films glass transition investigation" // IEEE Sens. J., 1-8, 2004.

5. R. Wolthuis, G. Mitchell, J. Hartl, and E. Saaski "Development of a dual function sensor system for measuring pressure and temperature at the tip of a single optical fiber" // IEEE Trans. Biomed. Eng., 40 (3), 298-302, 1993.

6. M. Giordano, M. Russo, A. Cusano, G. Mensitieri, and G. Guerra "Syndiotactic polystyrene thin film as sensitive layer for an optoelectronic chemical sensing device" // Sens. Actuators B, 2004.

7. A. A. Chtcherbakov, P. L. Swart, S. J. Spammer, $P$. V. Bulkin "Long dual-cavity fiber optic Fabry-Perot strain sensor with rugate mirrors" // Opt. Eng. 35(4), pp. 1059-1063, 1996.

8. V. Arya, M. J. de Vries, M. Athrya, A. Wang, R. O. Claus "Analysis of the effect of imperfect fiber endfaces on the performance of extrinsic Fabry-Perot interferometric optical fiber sensors" // Opt. Eng. 35(8), pp. 2262-2265, 1996.

9. A. M. Murphy, M. F. Gunther, A. M. Vengsarkar, and O. R. Claus "Quadrature phase-shifted, extrinsic Fabry-Perot optical fiber sensor" // Opt. Lett. 16(4), pp. 273-275, 1991.

10. Шаркань Й. П., Миголинеи И. М., Житов Н. Б., Мучичка И. И., Бандровская И. К., Конопальцева Л. И., Попович И. И., Гаврик Е. В. Способ определения градиента показателя преломления пленки по толщине // А. с СССР, № 1474524, 1987.

11. R. Todoran, J. P. Sharkany Nondestructive laser system for the in-situ study of the kinetics of the adsorption processes at solid/liquid interface // 1999, SPIE Proceedings Vol. 3687, Paper \#: 3687-05, pp. 26-28.

12. M. Giordanoa,., M. Russoa, A. Cusanob, G. Mensitieric An high sensitivity optical sensor for chloroform vapours detection based on nanometric film of $\Delta$-form syndiotactic polystyrene // Sensors and Actuators B: Chemical, Volume 107, Issue 1, 27 May 2005, p. 140147

13. O. N. Grigorov, A. I. Zaslavskii, Yu. V. Morachevskii // "Chemical Data", 2 $2^{\text {nd }}$ ed., Vol. 3, Moscow: "Khimia" 1965.

14. Зенин Г. С., Пенкина Н. В., Коган В. Е. Физическая химия: ч. 3. Фазовые равновесия и учение о растворах: Учебное пособие. -СПб.: СЗТУ, 2005. $-119 \mathrm{c}$. 